\title{
Implied Materiality and Material Disclosures of Credit Ratings
}

\section{Citation}

Eccles, Robert G., and Tim Youmans. "Implied Materiality and Material Disclosures of Credit Ratings." Harvard Business School Working Paper, No. 15-079, April 2015.

\section{Permanent link}

http://nrs.harvard.edu/urn-3:HUL.InstRepos:14425960

\section{Terms of Use}

This article was downloaded from Harvard University's DASH repository, and is made available under the terms and conditions applicable to Open Access Policy Articles, as set forth at http:// nrs.harvard.edu/urn-3:HUL.InstRepos:dash.current.terms-of-use\#OAP

\section{Share Your Story}

The Harvard community has made this article openly available.

Please share how this access benefits you. Submit a story.

\section{Accessibility}




\section{Implied Materiality and Material Disclosures of Credit Ratings}

Robert G. Eccles Tim Youmans

Working Paper 15-079 


\section{Implied Materiality and Material Disclosures of Credit Ratings}

Robert G. Eccles

Harvard Business School

Tim Youmans

Harvard Business School

Working Paper 15-079 


\title{
Implied Materiality and Material Disclosures of Credit Ratings
}

\author{
Robert G. Eccles and Tim Youmans ${ }^{1}$
}

\begin{abstract}
This first of three papers in our series on materiality in credit ratings will examine the materiality of credit ratings from an "implied materiality" and governance disclosure perspective. In the second paper, we will explore the materiality of environmental, social, and governance (ESG) factors in credit ratings' methodologies and introduce the concept of "layered materiality." In the third paper, we will evaluate current and potential credit rating agency (CRA) business models based on our analysis in the previous papers, and introduce the concept of "institutionalized materiality." Starting with this paper, and in the rest of the series, we will also recommend how the credit rating model can be enhanced in the coming years to help build more sustainable credit markets.

This first paper is focused on the "G" (governance) component of ESG reporting. The governance matters we identify in this paper must be addressed before turning our attention to the broader set of ESG considerations in credit ratings. Failure to put these important governance matters at the top of the credit ratings reform agenda would, in our opinion, undermine the efforts we will recommend in our second and third papers.
\end{abstract}

\footnotetext{
${ }^{1}$ Robert Eccles is a Professor of Management Practice and Tim Youmans is a Researcher at the Harvard Business School. The authors would like to thank Shannon Gombos and Leslie Martin for their outstanding research contributions to this paper. The authors are also grateful to David Colgren, Rob Fernandez, Charlotte Hamill, Tim Nixon, and Nick Robins for many helpful comments. None of these individuals necessarily agree with the conclusions of this paper. All errors are the authors'. Contact emails: reccles@hbs.edu and tyoumans@hbs.edu.
} 


\section{Introduction}

Credit rating agencies (CRAs) can play a vital role in ensuring fair, transparent, and efficient capital allocation through the provision of independent and unbiased ordinal ranking of the quality of debt issues. ${ }^{2}$ These ratings influence financial contracts, investment decisions, and securities regulations. Such rating assessments are a precondition to informed investor decisionmaking in regard to the trillions of dollars of corporate and sovereign debt securities annually brought to the bond market. ${ }^{3}$

In this paper we use the lens of materiality to take up the call for a deeper debate into the principles underlying the methodologies and business models of CRAs. Materiality defines the "reportability" boundary of economic, environmental, social, and governance (risk) issues, and identifies which issues receive the most resources and management attention. ${ }^{4}$ It is a concept that is at the core of financial, sustainability, and integrated reporting. In the U.S., financial reporting materiality guidance is provided by the Securities and Exchange Commission (SEC) and in case law. ${ }^{5}$ Materiality is a social construct that is entity-specific and audience-dependent; it is based on the judgment and oversight of the board of directors of the firm. ${ }^{6}$

While a fundamental but elusive concept in corporate reporting, materiality has yet to enter the longstanding debate about the role of CRAs in the financial markets. CRAs are both producers and consumers of materiality determinations. Thus, clarity in how CRAs describe the

\footnotetext{
${ }^{2}$ Among the 10 CRA's registered with the U.S. Securities and Exchange Commission as a nationally recognized statistical rating organization (NRSRO), approximately 95 percent of revenues are concentrated among the big three: Fitch, Moody's, and S\&P. Across all CRAs, approximately 115,000 corporate debt issues were outstanding in 2013 among the $\$ 2.44$ million in total obligations. "Annual Report on Nationally Recognized Statistical Rating Organizations." U.S. Securities and Exchange Commission, December 2014. http://www.sec.gov/ocr/reportspubs/annualreports/nrsroannrep1214.pdf. See Tables 1, 2 and 3.

3 "Debt Securities Statistics." Bank for International Settlements, March 18, 2015. http://www.bis.org/statistics/secstats.htm.

${ }^{4}$ Eccles, Robert G., and George Serafeim. "The Performance Frontier: Innovating for Sustainability." Harvard Business Review 91, no. 5 (2013): 50-60.

${ }^{5}$ Basic Inc. v. Levinson, 485 U.S. 224, 108 S. Ct. 978, 99 L. Ed. 2d 194 (1988) and TSC Industries vs. Northway, Inc., 426 U.S. 438,96 S. Ct. 2126 , 48 L. Ed. $2^{\text {nd }} 757$ (1976), amongst other cases.

${ }^{6}$ Eccles, Robert G., Michael P. Krzus, and Sydney Ribot. The Integrated Reporting Movement: Meaning, Momentum, Motives and Materiality. Chapter 5: John Wiley \& Sons, 2014.
} 
process by which they determine materiality is of critical importance to both the governance of their own firms and to the ratings products they bring to the financial markets.

We will argue that claims by CRAs about the independent and unbiased nature of their ratings are material information and should be included in their own disclosures. We will also argue that these claims represent the "implied materiality" of their ratings in the sense that investors making investment decisions regard independent ratings as an important part of the total mix of decision-relevant information, including investors evaluating the CRAs' own corporate disclosure information.

To summarize our conclusions, serious questions exist regarding the implied materiality of credit ratings as currently practiced. From an examination of their Form 10-K disclosures about their ratings products, we will show that CRAs have potential governance shortcomings that need to be addressed by the boards of the CRAs themselves. We will recommend ways to address these shortcomings. Our recommended CRA governance remedies aim to restore credit rating institutions to their historic role in the proper functioning of the global capital markets.

This paper is organized into five sections. After this introduction, section two discusses the role of credit rating agencies and introduces the concept of "implied materiality." Section three discusses the issue of material disclosures by CRAs regarding their ratings product. Section four analyzes the disclosures of McGraw Hill Financial (McGraw Hill), the owner of Standard \& Poors, and of Moody's, the owner of Moody's Investor Service, the world's two largest CRAs. Section five concludes with initial recommendations to move CRAs and their methodologies toward more rigorous attention to materiality and, finally, previews the papers that will follow. 


\section{The Role of Credit Rating Agencies in the Financial Markets}

The U.S. bond market has been larger than the stock market at year-end for 24 of the last 25 years, on average 79\% larger. ${ }^{7}$ From 2000-2007, the bond market grew at a faster rate than the economy and doubled in size, ${ }^{8}$ primarily due to the advent of asset-backed securities, which created a huge secondary market for securitized consumer debt. Since the 2007-2008 global financial crisis, however, the pattern of debt growth has changed. Sovereign debt has grown more robustly, while corporate debt growth is more mixed. The U.S. "Treasuries market increased from about $\$ 5$ trillion to $\$ 11$ trillion from the end of 2007 through $2012 . " 9$

Credit rating agencies play an essential role in the bond market. The ratings they provide are assessments, in the form of rankings, of the riskiness of debt issues, i.e., the likelihood that the bondholder will continue to receive interest payments and recover his or her principal. Bond ratings affect the cost of capital of the bond issuer in inverse proportion - the higher the rating, the lower the issuer's cost of capital. It is a practical reality that most corporate bonds, assetbacked securities and other bond classes need to be rated by a CRA. The credit rating determines whether or not a debt issue is "investment grade". "In practice the investment grade status for an issuer or [debt] issue is key as many investors are restricted by federal regulations, private contracts including rating triggers or investment guidelines to invest in investment grade instruments. ${ }^{, 10}$ Many institutional debt investors such as banks, pension funds, some sovereign wealth funds and many other investment funds are restricted from investing in debt that is not

\footnotetext{
${ }^{7}$ Shrout, Kurt. "The U.S. Bond Market May Be Much Different Than You Think It Is." LearnBonds, May 30, 2013. http://learnbonds.com/howbig-is-the-bond-market/.

${ }^{8}$ Tang, Kay. “Bond Market Size vs. Stock Market Size.” Zacks. http://finance.zacks.com/bond-market-size-vs-stock-market-size-5863.html, accessed November 23, 2014.

${ }^{9}$ Shrout, op. cit.

${ }^{10}$ Further, "Investment grade issue or issuer ratings are all ratings above BBB- or Baa- included." Langohr, Patricia, Essec Business School, cited in: "Definition of investment grade." Financial Times. http://lexicon.ft.com/Term?term=investment-grade, accessed April 8, 2015.
} 
investment grade. If debt issuers want to access this large market of potential buyers of their debt capital, they need to get their debt issues rated by a CRA.

While the bond market is large, only 10 companies are registered with the SEC to provide credit ratings. Each of these organizations is a Nationally Recognized Statistical Rating Organization (NRSRO), a designation by the SEC which registers these credit raters to operate in the publicly traded credit markets, essentially giving them some degree of legitimacy. ${ }^{11}$ The NRSRO credit ratings market is enormously concentrated. The "Big Three" CRAs — Standard \& Poors, Moody's, and Fitch Ratings (Fitch) — control about $95 \%$ of the market measured in terms of the number of ratings and revenues (Table 1). This is effectively an oligopoly with the position of these three organizations further strengthened by the fact that many debt instruments include "ratings triggers". CRA's reviews of previously issued ratings may result in ratings upgrades or downgrades possibly activating the trigger feature of the debt issue.

Borrowers are willing to include such triggers because, without them [or without CRAs' prior ratings reviews], lenders, out of fear of event risk, would demand a higher initial spread on debt contracts, or may not be willing to lend as much. Hence, issuers that are downgraded below investment grade to speculative grade see their cost of capital increase and their financing options diminish. The extent by which credit ratings from the global rating agencies are embedded in regulations and contracts is such that even investors that are not bound by these may have to react substantially to a downgrade to a speculative grade. $^{12}$

McGraw Hill and Moody's are public companies. Fitch is privately owned. In 2013, a total of 2,437,046 credit ratings were issued. Table 2 provides a detailed breakdown of this total for all 10 NRSROs by type of organization being rated: financial institutions, insurance companies, other corporations, asset-backed securities (special-purpose entities), and governments. The Big Three accounted for $96.6 \%$ of the total. They accounted for $91.7 \%$ of the

\footnotetext{
${ }^{11}$ Separate from the SEC, the European Securities and Markets Authority and the Swiss Financial Market Supervisory Authority recognize a total of $30+$ ratings agencies between them.

${ }^{12}$ Langohr, Patricia, op. cit.
} 
ratings of corporate issuers and $90.3 \%$ of those of asset-backed securities (Table 3). Clearly, the quality of the ratings work by the Big Three is critical for protecting the integrity of the bond markets.

In the wake of the 2007-2008 financial crisis, CRAs and their rating methodologies have been the subject of intense scrutiny in regard to their rigor, credibility, and role in serving the needs of the capital markets. Exemplifying a wide range of inquiries into the future role of CRAs, The Bank of England framed the question this way: "Whither the credit ratings industry?"13 This reflects a rising tide of government, investor, and academic questions regarding the scope and nature of possible reforms in the credit rating institutions and products that serve the global credit markets.

\section{The Implied Materiality of Credit Ratings}

SEC Regulation S-K requires that publicly listed companies disclose certain material information in their Form 10-K filings. "Material information" includes both quantitative (financial and nonfinancial) and qualitative information. The SEC, accounting bodies such as the Financial Standards Accounting Board, and courts in the U.S. have consistently stated that there is no simple algorithm, such as a percentage of profits, that can be used to determine if a fact is material or not. Instead, materiality is context specific and "there must be a substantial likelihood that the disclosure of the omitted fact would have been viewed by the reasonable investor as having significantly altered the 'total mix' of the information available."15 As a result, materiality is defined and implemented by individual entities according to their self-determined

\footnotetext{
${ }^{13}$ Deb, Pragyan, Mark J. Manning, Gareth Murphy, Adrian Penalver, and Aron Toth. "Whither the credit ratings industry?." Bank of England Financial Stability Paper 9 (2011): 20.

${ }^{14}$ Securities Act of 1933, Securities Exchange Act of 1934 and the Energy Policy and Conservation Act of 1975-Regulation S-K, 17 CFR 229.

Regulation S-K applies to financial and nonfinancial statement disclosures in a variety of filings, including but not limited to, Form 10-K filings.

${ }^{15}$ TSC Industries vs. Northway, Inc., op. cit., p. 449.
} 
concept of relevance. As a social construct, thinking about "material to whom" is essential in determining materiality. ${ }^{16}$ Audience matters.

The core issue surrounding the materiality of credit ratings in terms of their primary audience - providers of financial capital (investors) — is that credit ratings are assumed to be independent and unbiased and, as such, are of commercial value to these same investors. This effectively places credit ratings in the same category as the financial disclosures made by a company itself, giving them "implied materiality." The material financial disclosures of a public company are based on well-established accounting standards used by independent audit firms to provide an audit opinion on the company's financial statements. In the U.S., under the SarbanesOxley Act of 2002, the outside audit firm reports to the Audit Committee of the board of directors. This committee is charged with selecting the audit firm and establishing the audit's scope of work and price. ${ }^{17}$

Accounting standards enable an "apples-to-apples" comparison of the financial performance of different companies. Credit ratings are intended to do the same for the creditworthiness of debt issues. They also have an additional and very important role to play in eliminating "information asymmetries." The Bank of England Paper No. $9^{18}$ describes the underpinnings of the need for independent and unbiased second opinions to solve the market failure of information asymmetry by citing the well-known illustrative example of "lemons and cherries" in the used automobile market. ${ }^{19}$ Illustrating this, Grossman and Stiglitz (1980) have

\footnotetext{
${ }^{16}$ Eccles, Krzus, and Ribot, op. cit.

${ }^{17}$ The Sarbanes-Oxley Act also charges the audit committee with resolving disagreements between the auditors and management: "The audit committee of each issuer, in its capacity as a committee of the board of directors, shall be directly responsible for the appointment, compensation, and oversight of the work of any registered public accounting firm employed by that issuer (including resolution of disagreements between management and the auditor regarding financial reporting) for the purpose of preparing or issuing an audit report or related work, and each such registered public accounting firm shall report directly to the audit committee." Sarbanes-Oxley Act of 2002, PL 107204, 116 Stat 745, Section 301, Paragraph 2: "Responsibilities relating to registered public accounting firms."

${ }^{18}$ Deb, Manning, Murphy, Penalver, and Toth, op. cit., p. 4.

${ }^{19}$ Akerlof, George A. "The market for lemons: Quality uncertainty and the market mechanism." The Quarterly Journal of Economics (1970): 488500. In this example, hidden defects in used cars (lemons) disincent owners of well maintained cars (cherries) to sell, sometimes called the "bad
} 
shown how "A trusted and independent third party — a CRA — can help to reduce this information friction" in the market failure case of the uninformed investor vs. the informed investor. ${ }^{20}$ Independent and unbiased ratings are, by implication, material to investors.

The special status of NRSRO CRAs as a solution to market failure derives from the representations they make in maintaining their registration with the SEC. ${ }^{21}$ Absent their independent and unbiased nature, CRAs' ratings would be of limited value to investors, thus limiting the value of the firm providing the rating. They would also have limited value to the company being rated, which is the entity that pays for the rating under the current "issuer-pays" model.

\section{Disclosures Regarding the Materiality of Credit Ratings}

Owing to this combination of the practical necessity for credit ratings for nearly all debt securities, government designation, investor expectations, and expectations of the rated entity, it is the fiduciary duty of the board of directors of a CRA, or an entity which owns a CRA, to ensure that the company is making the necessary material disclosures regarding the independent and unbiased nature of the ratings. ${ }^{22}$ What is material depends upon which audience(s) the board deems to be particularly significant. In the case of CRAs, at least three audiences are clearly significant:

driving out the good." Hidden or withheld information creates the market failure of information asymmetry and can also lead to the market failure of adverse selection. Recommended solutions to these market failures are mandatory information disclosure.

${ }^{20}$ Deb, Manning, Murphy, Penalver, and Toth, op. cit., p. 4-5.

${ }^{21}$ A credit rating agency may apply to the SEC for registration as an NRSRO. The SEC's Office of Credit Ratings administers the SEC's rules relating to NRSROs, in addition to performing various other functions with respect to NRSROs and their registration status. "Credit Rating Agencies and Nationally Recognized Statistical Rating Organizations (NRSROs)." U.S. Securities and Exchange Commission. http://www.sec.gov/answers/nrsro.htm, accessed April 6, 2015. In 1975, the SEC created the NRSRO designation as a way to identify credit rating agencies whose ratings could be utilized to identify securities that qualify for certain investment purposes. The first three registered. NRSROs were Fitch, Moody's, and Standard \& Poors.

${ }^{22}$ Eccles, Krzus, and Ribot, op. cit. Furthermore, all directors individually sign the firm's annual SEC 10-K filing, in addition to the firm's CEO and CFO. 
1. Investors in CRAs: The decision of whether or not to invest in a CRA, or a company that owns one, will be influenced by claims regarding the independent and unbiased qualities of ratings' products. The implied materiality of credit ratings' claims about whether or not these ratings are independent and unbiased is part of the "total mix" of information considered in making an investment decision. ${ }^{23}$

2. Investors in rated debt: A credit rating which is independent and unbiased carries implied materiality and thus belongs in the "total mix" of all other material information used in deciding whether or not to buy a given debt security at a specific price. $^{24}$

3. Companies issuing rated debt: Credit ratings directly affect their cost of capital. Whether or not ratings are independent and unbiased is significant to issuers. They also pay for the ratings. If the products do not meet the criteria of being independent and unbiased, the rationale for paying for these ratings is dramatically reduced, even though in most cases issuers have little practical choice but to purchase these ratings. This raises the issue of "institutionalized materiality" which we will discuss in our third paper.

In sum, the foundation of the implied materiality of a credit rating for an issuing company depends upon a CRA disclosing that its ratings are independent and unbiased, which is a material disclosure by the CRA itself. When this is the case, the market can rely upon a credit rating in much the way it can rely upon the information disclosed by a company. In contrast, when the CRA denies the claim that its ratings are independent and unbiased, or withdraws a prior such claim, questions naturally arise about the relevance of the rating and of the company providing it. ${ }^{23}$ TSC Industries vs. Northway, Inc., op. cit., p. 449.
${ }^{24}$ Ibid. 


\section{The Cases of McGraw Hill Financial (Standard \& Poors) and \\ Moody's (Moody's Investor Service)}

Standard \& Poors, a business unit within McGraw Hill Financial, illustrates how the question of independence and unbiasedness looms large in contemporary debates about the practice and future of credit ratings. McGraw Hill has said that their claims about the independence of their credit ratings should not be taken at face value: "S\&P, a unit of McGraw Hill Financial Inc., has said statements about the integrity of its ratings are 'puffery' that cannot be a basis for the fraud lawsuit, filed on February 4, [2013] by the U.S. Department of Justice." ${ }^{25}$ In this lawsuit, the U.S. government sought $\$ 5$ billion in damages. ${ }^{26}$ "The government's complaint alleges, in detail, the ways in which none of S\&P's credit ratings represented the thing that they were supposed to represent, which was an objective assessment of creditworthiness, because business considerations infected the entire rating process," wrote U.S. District Judge David Carter, in Santa Ana, California. ${ }^{27}$ McGraw Hill's claim that its statements about the independent and unbiased nature of its ratings are commercial puffery was made in their motions to dismiss this case. In denying the motion to dismiss, Judge Carter wrote that:

[S\&P] repeatedly asserted that no reasonable investor would have relied on S\&P's claims of independence and objectivity. Regarding the question of materiality [emphasis added], S\&P argued that, since the issuer banks had access to the same information and models that S\&P analysts did, they could not have been fooled by faulty credit ratings. This begs the question: if no investor believed in S\&P's objectivity, and every bank had access to the same information and models as $\mathrm{S} \& \mathrm{P}$, is $\mathrm{S} \& \mathrm{P}$ asserting that, as a matter of law, the company's credit ratings service added absolutely zero material value [emphasis added] as a predictor of creditworthiness? ${ }^{28}$

\footnotetext{
${ }^{25}$ Stempel, Jonathan. "Judge lets U.S. pursue \$5-billion fraud lawsuit against S\&P." Reuters, July 17, 2013. http://www.reuters.com/article/2013/07/17/us-mcgrawhill-sandp-lawsuit-idUSBRE96G08620130717.

${ }^{26}$ On February 3, 2015, McGraw Hill and the U.S. Department of Justice announced that this case had been settled, with McGraw Hill agreeing to pay a of $\$ 1.5$ billion in fines and other payments. In the settlement agreement documents, McGraw Hill retracted certain claims it had made in during the case, but McGraw Hill did not retract the puffery claim. The settlement was also joined by 19 states the District of Columbia, and also by CalPERS, which had made separate similar fraud claims against McGraw Hill.

${ }^{27}$ U.S. v. McGraw-Hill Cos. et al., U.S. District Court, Central District of California, Case 2:13-cv-00779-DOC-JCG, Order Denying Defendants' Motion to Dismiss, Document 34, p.14, July 16, 2013.

${ }^{28} \mathrm{Ibid}$, p.12.
} 
Despite McGraw Hill's claims in court that the independent and unbiased nature of their credit ratings are mere puffery, the day that Judge Carter issued his ruling McGraw Hill said “We firmly believe S\&P's ratings were and are [emphasis added] independent and expect to show just that in court.",29

The following sheds light on the linkage between "puffery" and immateriality:

Puffery refers to an exaggeration or statement that no reasonable person would take as factual. It often occurs in the context of advertising and promotional testimonials. Puffery may be used as a defense to a warranty or fraud claim, to assert that the plaintiff shouldn't have relied on the statements in issue. Puffing generally is defined as 'exaggerated, vague, or loosely optimistic statements about a company that are deemed so immaterial and unworthy of reliance that they cannot serve as the basis for liability. The difference between a statement of fact and mere puffery rests in the specificity or generality of the claim.' Phoenix Payment Solutions, Inc. v. Towner, 2009 U.S. Dist. LEXIS 91978 (D. Ariz. Oct. 2, 2009) ${ }^{30}$

Judge Carter directly connected the "immateriality" definition of puffery to McGraw Hill's position that its claims about the independent and unbiased nature of its ratings were commercial puffery. In his concluding sentence in the "Puffery" section of his denial of McGraw Hill's motion to dismiss, Judge Carter wrote: "Here Defendants have failed to cite any court decision accepting S\&P's argument that its specific representations regarding the objectivity and independence of its ratings are immaterial, as a matter of law, to the end users of those ratings." 31 Clearly, if statements about the independent and unbiased nature of S\&P's ratings are not regarded as material, the implied materiality of these ratings for the companies being rated and the purchasers of their rated debt must be called into question.

\footnotetext{
${ }^{29}$ Stempel, op. cit.

30 "Puffery Law \& Legal Definition." U.S. Legal. http://definitions.uslegal.com/p/puffery/, accessed April 4, 2015.

${ }^{31}$ U.S. v. McGraw-Hill Cos. et al., Order Denying Defendants' Motion to Dismiss, p.12.
} 
In the recent settlement of the U.S. Department of Justice lawsuit against McGraw Hill in which the company agreed to pay $\$ 1.5$ billion $^{32}$ in fines and other payments (the Settlement), McGraw Hill was specifically not released from any terms or obligations related to McGraw Hill's required compliance with NRSRO-related regulations. Specifically, "Nothing in this Agreement in any way alters or affects the terms of any regulations put in place by the SEC with respect to Nationally Recognized Statistical Rating Organizations (NRSROs) or Defendants' obligations under any such regulations." ${ }^{, 33}$ To illuminate the governance problems caused by McGraw Hill's own claims that its independence and objectivity in credit ratings were immaterial puffery, Judge Carter cited that S\&P executives were fully aware that "SEC approval of [S\&P's] NRSRO status depended on S\&P managing conflicts of interest, and that S\&P executives made representations about objectivity to Congress in order to avoid stricter regulation of the issuer pays model." ${ }^{34}$ Given the specific conditions of the Settlement, McGraw Hill's puffery claim presents potential risk to the NRSRO registration status of McGraw Hill's S\&P ratings unit. This risk is potentially material information to investors in McGraw Hill and, if so, should be disclosed in its 2015 Form 10-K.

Based on the authors' analysis of McGraw Hill's Form 10-K filings for 2004-2014, the company presents a confusing picture. ${ }^{35}$ In its Form 10-K filings for years 2004-2011, McGraw Hill asserted multiple times in each filing that they provided independent credit ratings or words to that effect. In 2012's Form 10-K, McGraw Hill reduced the frequency with which it claimed that it provides independent credit ratings, saying instead that McGraw Hill is a provider of credit ratings (removing the modifier "independent") and of "independent ratings benchmarks."

\footnotetext{
${ }^{32}$ United States v. McGraw-Hill Cos. et al., No. CV 13-00779-DOC, Settlement Agreement, February 2, 2015. http://www.justice.gov/sites/default/files/opa/press-releases/attachments/2015/02/03/sp_settlement_agreement.pdf.

${ }^{33}$ Ibid, Section 16-e, p.28.

${ }^{34}$ U.S. v. McGraw-Hill Cos. et al., Order Denying Defendants' Motion to Dismiss, p.11.

${ }^{35}$ Ernst \& Young was the company's auditor for this entire period.
} 
In 2013's Form 10-K, McGraw Hill changed their independence claim entirely from that made in the previous eight Form 10-K filings to now saying that McGraw Hill was an "independent provider" of credit ratings and benchmarks, distancing the claim of independence from the nature of its ratings entirely and moving it to the nature of the firm. Also, in its 2012 and 2013 Form 10K filings, McGraw Hill introduced a statement that they "strive to be the leading provider of ... ratings and benchmarks.” Nowhere in the 2012 or 2013 Form 10-K filings did McGraw Hill claim that they provided independent credit ratings or any words to that effect. Finally, in 2014's Form 10-K, McGraw Hill continued the same absence of claims about the independence of its credit ratings. However, McGraw Hill did modify the previous year's "strive" statement by inserting the phrase "transparent and independent," stating that McGraw Hill "strive[s] to be the leading provider of transparent and independent benchmarks \& ratings." ${ }^{36}$ For unexplained reasons, over the past 10 years McGraw Hill appears to be continuously diminishing, especially since 2012, the strength of its claims regarding the independent and unbiased nature of the credit ratings it gives to the debt issues of thousands of companies. The slight "uptick" in 2014 simply adds to the confusion. Some explanation of these changes would be useful for those who rely upon these ratings in making investment decisions - both in rated debt and CRAs themselves. ${ }^{37}$

Given that the puffery claims made by McGraw Hill in court in 2013 are still standing, ${ }^{38}$ there is a clear contradiction when juxtaposing the 2002-2011 Form 10-K statements against their puffery claim. Both the puffery claim and the Form 10-K statements cannot be true.

\footnotetext{
${ }^{36}$ In McGraw Hill's 2012 and 2013 10-Ks, they also stated, immediately after the "strive" statement, that they seek to bring "transparency and independent insights to the markets we serve," or similar. In McGraw Hill's 2014 10-K, issued soon after the Settlement, the "transparency and independent insights" phrase was omitted.

${ }^{37}$ While the Settlement document clearly releases McGraw Hill from any civil liability to the U.S. Government (with the exclusion of any such liabilities arising out of NRSRO obligations, cited above), or to the states that were party to the settlement "relating to any statement or activities concerning the integrity, objectivity, independence and lack of influence from business concerns of their activities in connection with the issuance, confirmation, and surveillance of ratings...," (Settlement section 4-i, pp.4-5, then sections 10-11, pp. 17-25), McGraw Hill was specifically not released from any liability related to its potential liabilities from "Any private right of action" (Settlement section 12-d, p.25). Therefore, investors in McGraw Hill, or classes of these investors, will evaluate the meaning of these changing statements in the company's 10$K$ as they might affect the "total mix" of information used to decide on whether to buy or sell (per TSC v. Northway) McGraw Hill securities. ${ }^{38}$ See note 26 .
} 
Therefore, McGraw Hill could potentially face some legal risk from investors regarding their Form 10-K filings.

Like McGraw Hill, Moody's is a public company listed on the New York Stock Exchange. ${ }^{39}$ Similar to the case of McGraw Hill, the Department of Justice is now investigating Moody's' ratings of residential mortgage bonds issued in the years before the financial crisis. ${ }^{40}$

Based on the authors' analysis, Moody's CEO, CFO, Controller, and board directors similarly changed its Form 10-K disclosures regarding the independence of its credit rating products. Moody's has not asserted a "puffery” claim, as McGraw Hill has done. However, Moody's has taken a very clear position, starting in 2008, that the independence of its credit ratings is no longer a material disclosure. A review of Moody's Form 10-K filings for 2004-2007 reveals that the company asserted multiple times in each Form 10-K that it provided independent credit ratings and independent assessments of credit risk. ${ }^{41}$ However, in its 2008 Form 10-K filing and all subsequent ones, ${ }^{42}$ Moody's has removed any and all statements claiming that its ratings are independent.

\footnotetext{
${ }^{39}$ Due to Fitch's ownership structure, it does not file SEC Form 10-K. Fifty percent of Fitch Ratings parent, the Fitch Group, is owned by the Hearst Corporation, which is private, and $50 \%$ is owned by Fimalac, a French firm that has $12 \%$ of its shares held by the public on the Euronext Paris stock exchange, with the balance of Fimalac's shares controlled by a private entity. "About." FitchRatings.

https://www.fitchratings.com/about, accessed April 6, 2015. In its SEC NRSRO filings, Fitch claims that its ratings are independent: "Application for Registration as a Nationally Recognized Statistical Rating Organization (NRSRO) - Exhibit 3." U.S. Securities and Exchange Commission. https://www.fitchratings.com/web_content/nrsro/nav/NRSRO_Exhibit-3.pdf, accessed April 6, 2015.

${ }^{40}$ Martin, Timothy. "Moody's Shares Fall on Reports of DoJ Probe." Wall Street Journal, Moneybeat Online, February 2, 2015. http://blogs.wsj.com/moneybeat/2015/02/02/moodys-shares-fall-on-reports-of-doj-probe/, accessed April 8, 2015.

${ }^{41}$ PricewaterhouseCoopers was the company's auditor from 2004 through 2007.

${ }^{42}$ KPMG was its auditor for the period 2008-2014.
} 


\section{Conclusion and Next Steps}

Despite multiple lawsuits ${ }^{43}$ and investigations ${ }^{44}$ regarding the role that CRAs played in the financial crisis, revenues at all three of the major CRAs have surpassed pre-crisis levels. ${ }^{45}$ Moody's share price now exceeds its pre-crisis highs, and McGraw Hill is at its highest share price since 1999. "Moody's and S\&P now look more attractive as businesses than most other financial firms do."47 This data suggests that the market does not perceive the potential legal risk regarding the changing of Form 10-K ratings independence disclosures as a significant one.

However, a 2014 survey of its members by the CFA Institute found that " $67 \%$ of members agree that investors have become cautious regarding the use of CRAs in their investment processes. Only $27 \%$ agree that regulatory protections have ensured greater transparency of CRA processes.” ${ }^{48}$ Despite whatever level of confidence investors have in CRAs in the short term, biased ratings represent a substantial systemic risk to the financial markets (and society at large) that merits serious attention. This is a critical issue for the financial markets that for decades have relied on credit ratings as integral to investment decision making. The specter of ratings that do not support their implied materiality because they are not independent and unbiased endangers the CRAs' social license to operate, the commercial viability of their current business model, and the overall health of the financial markets.

The first step in restoring the real and perceived integrity of credit ratings is to address the issue of material disclosures, a matter of substantial consequence to both investors in CRAs

\footnotetext{
${ }^{43}$ The Settlement (see note 32) aggregated the Department of Justice lawsuit with the separate lawsuits by 19 states and the District of Columbia against McGraw Hill, in addition to the now settled lawsuit by CalPERS against McGraw Hill.

${ }^{44}$ The Department of Justice lawsuit and the state lawsuits against McGraw Hill that were resolved in the Settlement were preceded by investigations. Note 40 cites the report of Department of Justice' investigation of Moody's.

45 "Credit where credit's due." The Economist, April 19, 2014. http://www.economist.com/node/21601020/print.

${ }^{46}$ MCO: $\$ 73.71$ on February 9, 2007, and \$97.12 on March 13, 2015. MHFI: \$113.31 on January 22, 1999, and \$104.29 on March 13, 2015.

Google Finance. https://www.google.com/finance, accessed March 13, 2015.

47 "Credit where credit's due," op. cit.

48 "Credit Rating Agency Survey Results." CFA Institute, June 2014.

http://www.cfainstitute.org/Survey/credit_rating_agency_survey_report.pdf.
} 
and to the companies whose debt issues they rate. This is an issue of corporate governance (the "G" in ESG), to be addressed by the boards of directors of CRAs, particularly McGraw Hill and Moody's given that they are publicly traded companies with a combined ratings' market share of over $80 \% .^{49}$ These boards need to decide whether the claim that their ratings products are independent and unbiased is a material disclosure or not. If so, unequivocal statements to that effect $^{50}$ belong in these CRAs' Form 10-K filings to inform three significant audiences: those who invest in CRAs; those who invest in debt of companies rated by CRAs; and the boards and management of issuing companies whose cost of and access to capital is at stake.

If, on the other hand, the CRA boards deem that such ratings independence claims are no longer a material disclosure, all three significant audiences should be made aware of this fact and draw their own conclusions. Our view is that if this ratings independence claim is withdrawn or claimed to no longer be material, then the SEC needs to reconsider the NRSRO status granted to any CRAs that do not claim that the independent and unbiased nature of their ratings is a material disclosure. The potential effect that ratings independence claims have on maintaining their NRSRO registration is a serious governance issue for the boards of CRAs to consider.

In our second paper in this series, we will turn our attention to whether and how so-called nonfinancial environmental, social, and governance (ESG) issues are taken into account when credit ratings are issued. Our starting hypothesis for data gathering and analysis is that credit ratings factor in "G" issues more than they do the "E" and " $\mathrm{S}$ " ones. Given that companies and investors are increasingly factoring in ESG issues in their own decision-making, it is worth considering whether the CRAs should as well through "layered materiality," in which they factor into ratings what companies and investors regard as material ESG issues.

\footnotetext{
${ }^{49}$ See Table 1.

${ }^{50}$ For McGraw Hill, this means that they would also retract their puffery claim.
} 
Our third paper will examine CRA ownership structures and business models. Much has been written about this, particularly on challenges to the issuer pays model, which has a number of inherent problems. The fact that little has changed and that the CRAs have been relatively impervious to these concerns is based, we believe, on "institutionalized materiality." Whatever their quality, credit ratings have taken on a life of their own. Organizations that issue debt securities are, in practice, nearly required to get one. Some types of investors in debt securities are constrained in only being able to invest in debt securities that have a rating of a "investmentgrade" or higher. As a result, extant institutional structures have made these ratings a material reality; even if the foundation for implied and layered materiality is missing. 
Table 1: Credit Ratings Agency 2013 Market Share ${ }^{51}$

\begin{tabular}{|l|r|r|}
\hline Rating Agency & Number of Ratings & Revenue \\
\cline { 2 - 3 } McGraw Hill Financial (S\&P) & $46.2 \%$ & $42.1 \%$ \\
\hline Moody's & $37.0 \%$ & $39.6 \%$ \\
\hline Fitch & $13.4 \%$ & $12.8 \%$ \\
\hline 3 Major CRAs Total & $96.6 \%$ & $94.5 \%$ \\
\hline All CRAs Total & $100 \%$ & $100 \%$ \\
\hline
\end{tabular}

\section{Table 2: Number of Outstanding Credit Ratings by Rating Category as of December 31, $2013^{52}$}

\begin{tabular}{|c|c|c|c|c|c|c|}
\hline \multicolumn{7}{|c|}{ Chart 1: Number of Outstanding Credit Ratings as of December 31, 2013 by Rating Category* } \\
\hline NRSRO & $\begin{array}{l}\text { Financial } \\
\text { Institutions }\end{array}$ & $\begin{array}{l}\text { Insurance } \\
\text { Companies }\end{array}$ & $\begin{array}{l}\text { Corporate } \\
\text { Issuers }\end{array}$ & $\begin{array}{l}\text { Asset- } \\
\text { Backed } \\
\text { Securities }\end{array}$ & $\begin{array}{l}\text { Government } \\
\text { Securities }\end{array}$ & $\begin{array}{l}\text { Total } \\
\text { Ratings }\end{array}$ \\
\hline A.M. Best & N/R & 4,492 & 1,653 & 56 & $\mathrm{~N} / \mathrm{R}$ & 6,201 \\
\hline DBRS & 13,624 & 150 & 3,790 & 10,706 & 16,038 & 44,308 \\
\hline EJR & 104 & 46 & 877 & $\mathrm{~N} / \mathrm{R}$ & $\mathrm{N} / \mathrm{R}$ & 1,027 \\
\hline Fitch & 49,821 & 3,222 & 15,299 & 53,612 & 204,303 & 326,257 \\
\hline HR Ratings & N/R & $\mathrm{N} / \mathrm{R}$ & N/R & N/R & 189 & 189 \\
\hline JCR & 150 & 27 & 463 & $\mathrm{~N} / \mathrm{R}$ & 56 & 696 \\
\hline KBRA & 15,982 & 44 & 2,749 & 1,401 & 25 & 20,201 \\
\hline Moody's & 53,383 & 3,418 & 40,008 & 76,464 & 728,627 & 901,900 \\
\hline Morningstar & $\mathrm{N} / \mathrm{R}$ & $\mathrm{N} / \mathrm{R}$ & $\mathrm{N} / \mathrm{R}$ & 11,567 & $\mathrm{~N} / \mathrm{R}$ & 11,567 \\
\hline S\&P & 59,000 & 7,200 & 49,700 & 90,000 & 918,800 & $1,124,700$ \\
\hline Total & 192,064 & 18,599 & 114,539 & 243,806 & $1,868,038$ & $2,437,046$ \\
\hline
\end{tabular}

Source: NRSRO annual certifications for the calendar year ended December 31, 2013, Item 7A on Form NRSRO

$* \mathrm{~N} / \mathrm{R}$ indicates that the NRSRO is not registered for the rating category indicated.

\footnotetext{
${ }^{51}$ Calculated from the most recent (2013) NRSRO filings with the SEC and corresponding CRA 2013 SEC 10-K filings. Note that the 2014 SEC Annual Report on NRSROs, issued on December 2014, "relates generally to the period from June 26, 2013 to June 25, 2014" (report p.1). Further, the cover of the report contains the following statement "This is a report of the staff of the U.S. Securities and Exchange Commission. The Commission has expressed no view regarding the analysis, findings, or conclusions contained in this report." "Annual Report on Nationally Recognized Statistical Rating Organizations." U.S. Securities and Exchange Commission, December 2014.

http://www.sec.gov/ocr/reportspubs/annual-reports/nrsroannrep1214.pdf.

${ }^{52}$ lbid.
} 
Table 3: Market Share of Fitch, Moody's, and S\&P by Rating Category as of December 31, 2013 ${ }^{53}$

Chart 8: Total Ratings

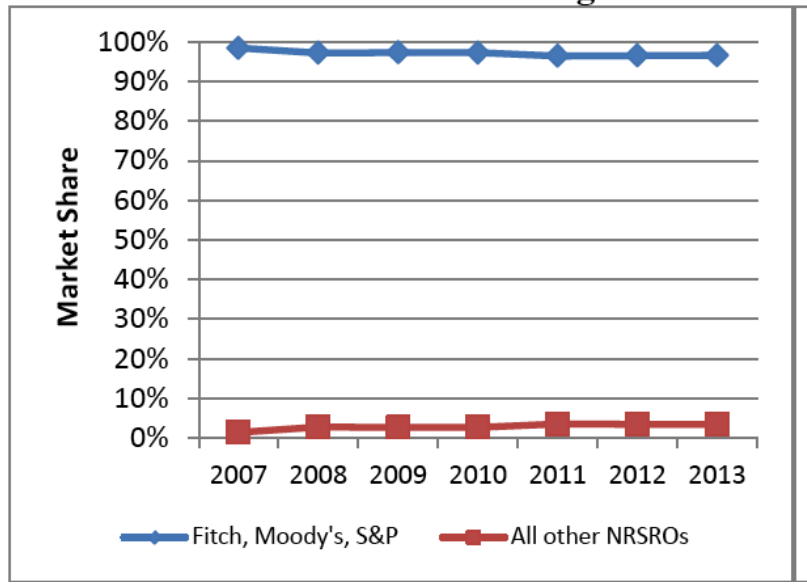

Chart 10: Insurance Companies

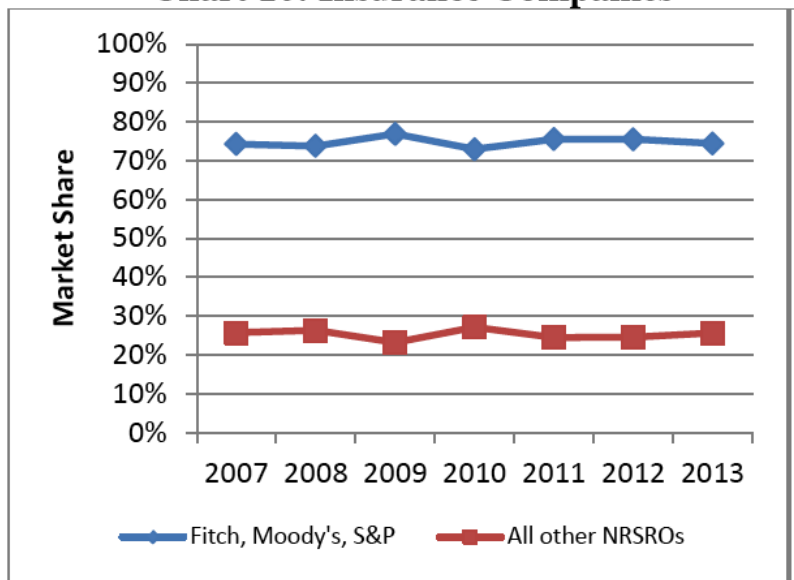

Chart 12: Asset-Backed Securities

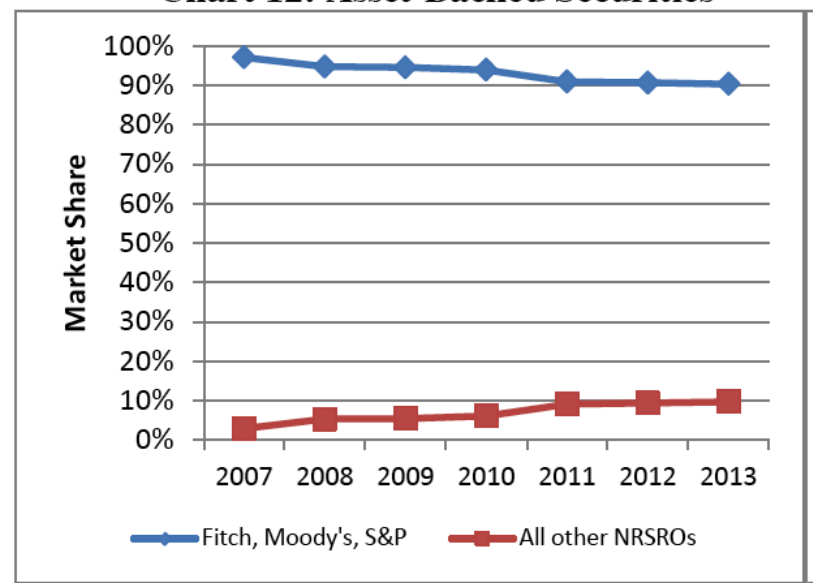

Chart 9: Financial Institutions

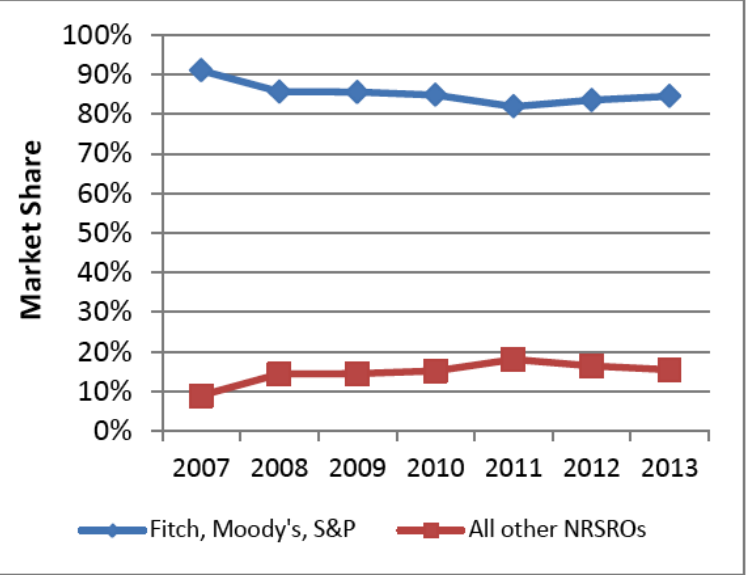

Chart 11: Corporate Issuers

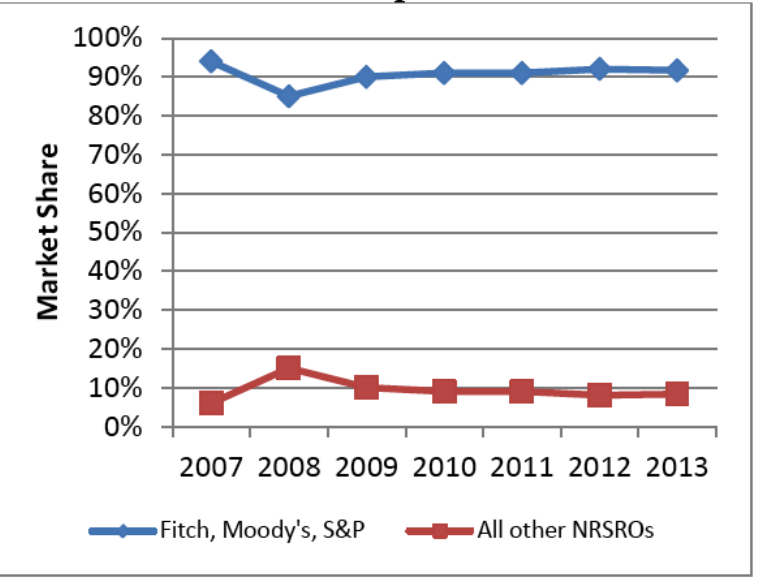

Chart 13: Government Securities

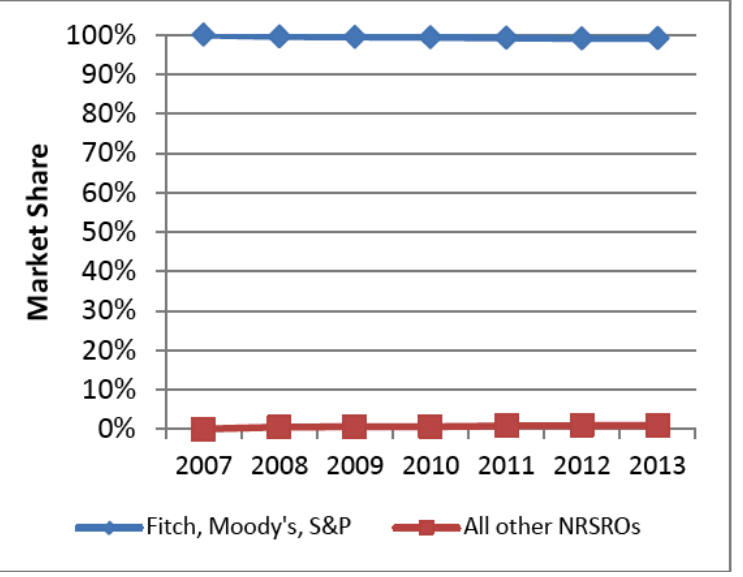

${ }^{53}$ Ibid. 